Agro-Science Journal of Tropical Agriculture, Food, Environment and Extension Volume 19 Number 4 (October 2020) pp. 14 - 17

TSSN 1119-7455

\title{
ORGAN WEIGHTS AND BIOCHEMICAL INDICES OF BROILER CHICKENS FED DIETS CONTAINING Saccharomyces cerevisiae
}

\author{
${ }^{* 1}$ Osita C.O., ${ }^{1}$ Ani A.O., ${ }^{2}$ Ugwuowo L.C., ${ }^{1,3}$ Akuru E.A. and ${ }^{1}$ Njoku S. \\ ${ }^{1}$ Department of Animal Science, University of Nigeria, Nsukka, Nigeria \\ ${ }^{2}$ Department of Animal Science, Nnamdi Azikiwe University Awka, Anambra State, Nigeria \\ ${ }^{3}$ Department of Livestock \& Pasture Science, University of Fort Hare, Alice 5700, South Africa \\ *Corresponding author's email: charles.osita@unn.edu.ng
}

\begin{abstract}
A study was conducted to evaluate the organ weights and biochemical indices of broiler chickens fed diets containing varying levels of Saccharomyces cerevisiae. One hundred and twenty (120) broiler birds were used for the experiment. The birds were weighed and randomly allocated into four treatment groups. Each treatment was replicated three times with 10 birds per replicate. Treatment 1 served as the control and did not contain any S. cerevisiae supplement, while treatments 2,3 and 4 contained $0.7,1.2$ and $1.7 \mathrm{~g} / \mathrm{kg}$ of $\mathrm{S}$. cerevisiae supplement, respectively. The experiment lasted for eight weeks. At the end of the feeding trial (day 56), two birds were randomly picked from each replication for carcass evaluation and another two birds were randomly selected from each pen and 5mlblood was collected f from the wing vein using sterile disposable syringe for biochemical analysis. The result of this study showed that there were no significant $(p>0.05)$ differences among treatments in kidney, spleen and pancreas weights while significant $(p<0.05)$ differences among treatments existed in the heart, gizzard and liver weights. The study also revealed that there were no significant $(p>0.05)$ differences among treatments in total protein, globulin and high density lipoprotein levels while albumin, total cholesterol, glucose and triglyceride were significantly $(p<0.05)$ affected. In T3 highest heart weight ( $0.33 \%$ of live weight) and lowest blood cholesterol concentration (91.77 mg/dl) were recorded and therefore T3 was recommended. Low blood cholesterol enhances broiler production.
\end{abstract}

Key words: albumin, cholesterol, kidney, liver, yeast

\section{INTRODUCTION}

There is a public and scientific concern about the widespread use of antibiotics and the possibility for transfer of antibiotic resistance to human pathogenic bacteria (Parvez et al., 2006). In addition, the presence of antibiotic residues in the meat may have deleterious effect on human consumers. For these reasons the European Union banned the use of antibiotics for non-therapeutic purposes in January 01, 2006. It is therefore imperative to find safe alternatives to the use of antibiotics. Hence, alternatives like probiotics are being used in poultry feed to improve production performance (Onifade, 1998). Probiotic is defined as a live microbial feed supplement which beneficially affects the host animal by improving its intestinal microbial balance (Fuller, 2001). Yeast has been used as a probiotic in animal feed (Saegusa et al., 2004). Saccharomyces cerevisiae, one of the most widely commercialized type of yeast, has long been fed to poultry. Saccharomyces cerevisiae is a rich source of protein, vitamin $\mathrm{B}$ complex, trace minerals and many other beneficial factors (Reed and Nagodawithana, 1991). It can improve body weight gain, feed efficiency, stimulate the immunity system and increase its defensive activity against pathogenic bacteria and also reduces feed cost by shortening the length of feeding (Mohamed et al., 2015; Patane et al., 2017).

Lutful Kabir (2009) stated that the yeast acts by (i) maintaining normal intestinal microflora by competitive exclusion and antagonism (ii) altering metabolism by increasing digestive enzyme activity and decreasing bacterial enzyme activity and (iii) stimulating the immune system. The study was designed to evaluate the effects of dietary inclusion of Saccharomyces cerevisiae on organ weights, and biochemical indices of broiler chickens.

\section{MATERIALS AND METHODS}

The study was carried out at the Poultry Unit of the Department of Animal Science Teaching and Research Farm, University of Nigeria, Nsukka. The study lasted for eight weeks. The experimental procedures complied with the provisions of the University of Nigeria, Nsukka Ethical Committee on the Use of Animals for Biometric Research. 


\section{Experimental Animals and Management}

One hundred and twenty commercial broilers of Anak strain were used for the study. The birds were weighed and randomly allocated into four treatment groups having 30 birds per treatment in a completely randomized design. Each treatment was replicated three times with 10 birds per replicate. Treatment 1 served as the control and does not contain Saccharomyces cerevisiae, while treatments 2,3 , and 4 , respectively contained $0.7,1.2$, and 1.7 $\mathrm{g} / \mathrm{kg}$ of $S$. cerevisiae supplementation. Broiler starter and finisher diets were formulated. The percentage of ingredients composition used in formulating starter and finisher rations are shown in Table 1. Clean water and feed were provided $a d$ libitum. The required drugs and vaccinations were administered appropriately according to the vaccination routine for broilers. Other health precautions and disease control measures were taken throughout the study period. The experimental diets were assayed for proximate composition (Table 2) by the method of the Association of Official Analytical Chemist (AOAC, 1995).

\section{Relative Organs Weights}

At the end of the feeding trial (on 56 day of age), two birds were randomly picked from each replication for carcass evaluation. The birds were slaughtered after being starved for about 12 hours and weighed. These birds were de-feathered completely and eviscerated. The kidney, pancreas, heart, liver, gizzard and spleen were collected, weighed and their percentages were determined in relation to live weight.

\section{Blood Collection}

Six birds were randomly selected from each treatment at the end of the experiment and $5 \mathrm{mlblood}$ was collected from each bird, from the wing vein using sterile disposable syringe and emptied into sample bottles for biochemical analysis. The total protein concentration was determined using the Tietz (1995) method while the serum albumin concentration was determined using the method of Grant et al. (1987). The determination of the plasma globulin level was by the following formula:

Plasma globulin $=$ Total protein - Plasma albumin. The total plasma cholesterol, high density lipoprotein, glucose and triglycerides were determined by adopting the protocol outlined in the manufacturer's assay kit from $\mathrm{M} / \mathrm{s}$ Randox Laboratories Ltd, Ardmore, Co. Antrim, UK.

\section{Statistical Analysis}

Data collected were subjected to one-way model of analysis of variance in a completely randomized design as described by Steel and Torrie (1980) using Statistical Package for the Social Sciences (2003). Significant differences between treatment means were separated using Duncan's New Multiple Range Test (Duncan, 1955). The treatment effects were considered significant at $p<0.05$.

\section{RESULTS \\ Organ Weights}

The results of the effects of Saccharomyces cerevisiae supplementation on internal organs of broilers are shown in Table 3. There were significant $(p<0.05)$ differences among the treatments in heart, liver and gizzard weights while no significant $(p>0.05)$ difference existed in kidney, pancreas and spleen weights. The relative heart weight value of birds on T3 diet was the highest while the least value was recorded on $\mathrm{T} 1$. The liver weights values of birds on T3 and T4 diets were similar but were significantly $(p<0.05)$ higher than those of birds on T1 and T2 diets. The gizzard weight of birds on T1 (control) diet was lower than those of birds on other treatment groups.

\section{Biochemical Indices.}

The effects of $S$. cerevisiae supplementation on biochemical indices of broilers are shown in Table 4. There were significant $(p<0.05)$ differences among the treatments in total cholesterol, albumin, glucose and triglycerides while no significant $(p>0.05)$ differences existed among treatments in total protein, globulin and high density lipoprotein. Birds fed diets without $S$. cerevisiae supplementation had the highest $(p<0.05)$ cholesterol, albumin, glucose and triglycerides concentrations.

Table 1: Percentages of ingredients used in starter and finisher rations formulation

\begin{tabular}{lcc}
\hline Ingredients & Starter (\%) & Finisher (\%) \\
\hline Maize & 30.00 & 28.62 \\
Wheat offal & 12.00 & 28.62 \\
Palm Kernel Cake & 20.00 & 18.13 \\
Soyabean meal & 29.50 & 18.13 \\
Fish meal & 4.00 & 2.00 \\
Lysine & 0.25 & 0.25 \\
Methionine & 0.25 & 0.25 \\
Premix & 0.50 & 0.50 \\
Salt & 0.50 & 0.50 \\
Oyster shell & 3.00 & 3.00 \\
Total & 100.00 & 100.00 \\
CalculateCrude protein & 23.30 & 19.50 \\
Metabolizable energy $(\mathrm{kCal} / \mathrm{kg})$ & 2880.00 & 3008.00 \\
\hline
\end{tabular}

Table 2: Proximate composition of the experimental diets

\begin{tabular}{lcc}
\hline & Starter (\%) & Finisher (\%) \\
\hline Crude protein & 23.42 & 20.85 \\
Ash & 5.33 & 6.13 \\
Ether extract & 4.39 & 5.74 \\
Crude fibre & 2.10 & 2.62 \\
Moisture & 8.72 & 7.90 \\
Nitrogen free extract & 56.04 & 56.76 \\
\hline
\end{tabular}


Table 3: Organs weights of broiler chickens fed diets supplemented with Saccharomyces cerevisiae

\begin{tabular}{|c|c|c|c|c|c|}
\hline \multirow[b]{2}{*}{ Parameters } & \multicolumn{4}{|c|}{ Treatments } & \multirow[b]{2}{*}{ SEM } \\
\hline & $\begin{array}{c}\mathrm{T} 1 \\
\text { (control) }\end{array}$ & $\begin{array}{c}\mathrm{T} 2 \\
(0.7 \mathrm{~g} / \mathrm{kgSC})\end{array}$ & $\begin{array}{c}\mathrm{T} 3 \\
(1.2 \mathrm{~g} / \mathrm{kgSC})\end{array}$ & $\begin{array}{c}\mathrm{T} 4 \\
(1.7 \mathrm{~g} / \mathrm{kgSC})\end{array}$ & \\
\hline \multicolumn{6}{|c|}{ Internal organs ( $\%$ of live weight) } \\
\hline Heart & $0.19^{c}$ & $0.28^{b}$ & $0.33^{\mathrm{a}}$ & $0.27^{\mathrm{b}}$ & 0.06 \\
\hline Liver & $0.61^{b}$ & $0.60^{\mathrm{b}}$ & $0.79^{\mathrm{a}}$ & $0.78^{\mathrm{a}}$ & 0.12 \\
\hline Kidney & 0.18 & 0.17 & 0.21 & 0.19 & 0.08 \\
\hline Pancreas & 0.15 & 0.16 & 0.18 & 0.17 & 0.07 \\
\hline Gizzard & $1.38^{\mathrm{b}}$ & $1.63^{\mathrm{a}}$ & $1.65^{\mathrm{a}}$ & $1.68^{\mathrm{a}}$ & 0.04 \\
\hline Spleen & 0.12 & 0.10 & 0.16 & 0.18 & 0.02 \\
\hline
\end{tabular}

Table 4: Biochemical indices of broiler chickens fed diets supplemented with Saccharomyces cerevisiae

\begin{tabular}{|c|c|c|c|c|c|}
\hline \multirow[b]{2}{*}{ Parameters } & \multicolumn{4}{|c|}{ Treatments } & \multirow[b]{2}{*}{ SEM } \\
\hline & $\begin{array}{c}\mathrm{T} 1 \\
\text { (control) }\end{array}$ & $\begin{array}{c}\mathrm{T} 2 \\
(0.7 \mathrm{~g} / \mathrm{kg} \mathrm{SC})\end{array}$ & $\begin{array}{c}\mathrm{T} 3 \\
(1.2 \mathrm{~g} / \mathrm{kg} \mathrm{SC})\end{array}$ & $\begin{array}{c}\mathrm{T} 4 \\
(1.7 \mathrm{~g} / \mathrm{kg} \mathrm{SC})\end{array}$ & \\
\hline Total protein $(\mathrm{g} / \mathrm{dl})$ & 3.07 & 2.87 & 3.19 & 2.99 & 0.43 \\
\hline $\operatorname{Albumin}(\mathrm{g} / \mathrm{dl})$ & $1.53^{\mathrm{a}}$ & $1.23^{\mathrm{b}}$ & $1.02^{\mathrm{c}}$ & $1.26^{\mathrm{b}}$ & 0.20 \\
\hline Total cholesterol (mg/dl) & $137.07^{\mathrm{a}}$ & $108.77^{b}$ & $91.77^{\mathrm{c}}$ & $110.57^{b}$ & 6.80 \\
\hline $\mathrm{HDL}(\mathrm{mg} / \mathrm{dl})$ & 86.83 & 97.73 & 85.63 & 95.23 & 5.10 \\
\hline Glucose (mg/dl) & $215.5^{\mathrm{a}}$ & $175.6^{\mathrm{b}}$ & $143.7^{\mathrm{c}}$ & $137.4^{\mathrm{c}}$ & 6.40 \\
\hline Globulin (g/dl) & 1.54 & 1.64 & 2.17 & 1.73 & 0.29 \\
\hline Triglyceride (mg/dl) & $65.13^{\mathrm{a}}$ & $55.22^{b}$ & $45.25^{\mathrm{c}}$ & $44.33^{\mathrm{c}}$ & 4.21 \\
\hline
\end{tabular}

\section{DISCUSSION}

\section{Organ Weights}

The present results agree with that of Dimcho et al. (2005) and Onwurah and Okejim (2014) who reported improvements in liver, gizzard and heart of broilers, mules and ducklings by supplementing diets with probiotics. The increase in the gizzard and liver weights may suggest increased digestibility and metabolism and hence a higher efficiency of feed and nutrients utilization. The present results are in accordance with the findings of Mandal et al. (1996), who stated that there was no effect on kidney and pancreas weights when broilers were fed diets supplemented with probiotics.

However, the result of this study is in contrast with the findings by Hussein and Selim (2018) who reported that dietary probiotic supplementation did not increase the liver weights of broiler chickens. The observed inconsistency might be attributed to the strains of probiotic, technique of preparation, administration dosage, diet composition and hygienic status ((Zhang et al., 2012).

\section{Biochemical Indices}

The results of present study are consistent with Paryad and Mahmoudi (2008) and Gudev et al. (2008) who found that broiler chicks fed ration containing $S$. cerevisiae had significantly lower plasma cholesterol, albumin and triglycerides. Probiotics could contribute to the regulation of serum cholesterol concentrations by deconjugation of bile acids (Paryad and Mahmoudi, 2008). Since the excretion of deconjugated bile acids is enhanced and cholesterol is its precursor, more molecules are spent for therecovery of bile acids (De Smet et al., 1994). As a result of increased synthesis of this acids, it is expected that the level of serum cholesterol to be reduced. Klaver and Van Der Meer (1993) suggested that co-precipitation with bile acids might be of importance for decreasing of serum cholesterol concentrations cerevisiae might have played an important role in reducing the levels of cholesterol in the blood of broiler chickens by affecting their absorption and metabolism (Klaver and Van Der Meer, 1993). Besides, it might have helped in binding the cholesterol to the cellular surface and incorporated in the cellular membrane during growth (Chiang et al., 2008).

The results of the present study are also in line with Konca et al. (2009) who reported that inclusion of yeast into diets of turkey toms does not affect serum levels of total protein and globulin. In contrast to our result, Konca et al. (2009) and Yalcin et al. (2013) reported that inclusion of yeast into diets of turkey toms does not affect serum levels of triglycerides. The result of the present study also disagrees with Babu et al. (2016) who reported that yeast supplementation in the diet of broilers significantly increased glucose, cholesterol and triglyceride levels. Our result supports the findings of Gudev et al. (2008) and Onifade et al. (1999) who reported a decrease in blood glucose for chicks fed diets containing yeast. This reduced blood glucose level may be due to the suppressive effect of $S$. cerevisiae on glucagons, which otherwise increases blood glucose in chickens, thereby maintaining blood glucose homeostasis. 


\section{CONCLUSION}

In T3 (1.2 g/kg Saccharomyces cerevisiae) higher heart weight $(0.33 \%$ of live weight $)$ and lower blood cholesterol concentration $(91.77 \mathrm{mg} / \mathrm{dl})$ were recorded and therefore $\mathrm{T} 3$ was recommended. Lower blood cholesterol enhances broiler production.

\section{REFERENCES}

AOAC (1995). Association of Official Analytical Chemists, Official Methods of Analysis, (14 ${ }^{\text {th }}$ ed.), Washington, DC, 1018

Babu K.N., Mohammad A.H., Mukti B., Kamrul I. and Gouranga C.C. (2016). Growth performance and serum biochemical responses of commercial broilers fed diets containing rubber seed and yeast. Asian $J$. Poult. Sci., 10, 96-103

Chiang Y.R., Ismail W., Heintz D., Schaeffer C., Van Dorsselaer A. and Fuchs G. (2008). Study of anoxic and oxic cholesterol metabolism by Sterolibacterium denitrificans. J. Bacteriol., 190, 905-914

De Smet I., VanHoorde L., De Saeyer V., Woeslyne M. and Verstraele W. (1994). In vitro study of bile salt hydrolase (BSH) activity of $\mathrm{BSH}$ isogonics Lactobacillus plantarum 80 strains and estimation of cholesterol lowering through enhanced BSH activity. Microb. Ecol. Health Dis., 7, 315-329

Dimcho D., Svetlana B., Tsvetomira S. and Tatiana V. (2005). Effect of feeding Lactina probiotic on performance, some blood parameters and caecal microflora of mule ducklings. TJS, 3, 22-28

Duncan D.B. (1955). Duncan New Multiple Range Test. Biometrics, 11, 1-42

Fuller R. (2001). The chicken gut microflora and probiotic supplements. J. Poul. Sci., 38, 189-196

Grant G.H., Silverman L.M. and Christenson R.H. (1987). Amino acids and proteins. In: Tietz N.W. (ed.), Fundamentals of Clinical Chemistry, 291-345. W.B. Saunders Company, London

Gudev D., Popova-Ralcheva1 S., Moneva1 P. and Ignatova M. (2008). Effect of the probiotic "Lactona" on some biological parameters and nonspecific resistance in neonatal pigs. Biotechnol. Anim. Husbandry, 24, 87-96

Hussein E.S. and Selim S. (2018). Efficacy of yeast and multi-strain probiotic alone or in combination on growth performance, carcass traits, blood biochemical constituents, and meat quality of broiler chickens. Livest. Sci., 216, 153-159

Klaver F.A.M. and Van der Meer R. (1993). The assumed assimilation of cholesterol by Lactobacilli and Bifidobacterium bifidum is due to their bile salt deconjugating activity. Appl. Environ. Microbiol., 59, $1120-1124$

Konca Y., Kirkpinar F., Mert S. and Kayhan B. (2009). Performance, intestinal microflora and blood constituents in finishing turkeys fed diets supplemented with dietary mannan oligosaccharide and live yeast. J. Animal Feed Sci., 18, 508-517

Lutful Kabir S.M. (2009). The role of probiotics in the poultry industry. Int. J. Mol. Sci., 10, 3531-3546
Mandal S. K., Biswas I.K. and Mandal L. (1996). Efficiency of different growth promoters on the performance of broilers. Indian J. Poul. Sci., 92, 13-17

Mohamed E.A., Talha E.A., Mojahid A.A. and Dafaalla E.M. (2015). Effect of dietary yeast (Saccharomyces cerevisiae) supplementation on performance, carcass characteristics and some metabolic responses of broilers. Animal Vet. Sci., 3, 5-10

Onifade A.A. (1998). Proposing fortification of foods with yeast for optimal nutrition value and salubrious effects. Nutri. Food Sci., 98, 223-226

Onifade A., Odunsi A.A., Babatunde G.M., Olorede B.R. and Muma E. (1999). Comparison of the supplemental effects of Saccharomyces cerevisiae and antibiotics in low-protein and high-fiber diets fed to broiler chickens. Arch. Anim. Nutri., 52,29-39

Onwurah F.B. and Okejim J.C. (2014). Effect of graded levels of baker's yeast (Saccharomyces cerevisiae) in water on carcass and organ characteristics of broiler chickens. Acad. Res. Int., 5, 128-133

Parvez S., Malik K.A., Kang S.A. and Kim H.Y. (2006). Probiotics and their fermented food products are beneficial for health. J. Appl. Microbiol., 100, 1171-1185

Paryad A. and Mahmoudi M. (2008). Effect of different levels of supplemental yeast (Saccharomyces cerevisiae) on performance, blood constituents and carcass characteristics of broiler chicks. Afr. J. Agric., 3, 835-842

Patane A.S., Premavalli K., Omprakash A.V., John Kirubakaran J. and Hudson G.H. (2017). Effect of dietary yeast supplementation on the production performance of broilers. IJABR, 7, 222-228

Reed G. and Nagodawithana T.W. (1991). Yeast Technology ( $3^{\text {rd }}$ ed.), Van Nostrand Reinhold, New York, USA, 10-15

Saegusa S., Totsuka M., Kaminogawa S. and Hosoi T. (2004). Candida albicans and Sacchromyces cerevisiae induce interlukin- 8 production from intestinal epithelial-like $\mathrm{CaCO}-2$ cells in the presence of butyric acid. FEMS Immunol. Med. Microbiol., 41, 227-235

SPSS (2003). Statistical Package for Social Sciences, Windows Version 8. SPSS Inc. USA

Steel R.G.D. and Torrie J.H. (1980). Principles and Procedures of Statistics: A Biometric Approach. ( $2^{\text {nd }}$ ed.) McGraw-Hill Publishers, New York, 47

Tietz, N.W. (1995). Clinical Guide to Laboratory Tests. ( $3^{\text {rd }}$ ed.). W.B. Saunders, Philadelphia, 22-25

Yalcın S., Eser H., Yalcın S., Cengiz S. and Eltan O. (2013). Effects of dietary yeast autolysate (Saccharomyces cerevisiae) on performance, carcass and gut characteristics, blood profile, and antibody production to sheep red blood cells in broilers. J. Appl. Poult. Res., 22, 55-61

Zhang Z.F., Zhou T.X., Ao X. and Kim I.H. (2012). Effects of $\beta$-glucan and Bacillus subtilis on growth performance, blood profiles, relative organ weight and meat quality in broilers fed maize-soybean meal based diets. Livest. Sci., 150, 419-424 